\title{
College students "peer support" education mode
}

\author{
Xin-Hua YAO and Yun-Heng ZHENG * \\ Beihua University ,Jilin, China \\ *Corresponding author: Yun-Heng ZHENG
}

Keywords: peer support; education mode; exploration

\begin{abstract}
The university to carry out the "peer support" has important practical significance to education, on the one hand is an important supplement to carry out the ideological and political education, on the other hand is an effective means of students' self education, also enhance the innovative ways of Ideological and political education appeal. The combination of tradition and innovation and the principle of equality and the appropriate combination of peer education is an important principle to follow in the main work. Improve the "peer support" education system, strengthen the comprehensive ability of peer educators, build a multi-dimensional education platform is an effective strategy of "peer support" education mode in Colleges and universities.

"Peer support" education is the important content of China's colleges and universities to carry out ideological and political education. Through the exchange of learning with the same background and similar experiences of friends or peers, and to form a correct outlook on life and values, in a lofty ideal and firm faith at the same time, it is helpful to solve university student occupation career planning, interpersonal relationships and mental health problems. With the continuous development of China's higher education, college enrollment has expanded each year, according to the characteristics of students self management and development of innovative education and practice management mode is an important issue facing the ideological and political education work.
\end{abstract}

\section{Practical significance in Colleges and universities "peer support" Education}

It is an important supplement to the way of Ideological and Political Education. Ideological and political education in Colleges and universities is an important part of college students education. University stage is the critical period for the formation of students' thinking consciousness, and is the best period for ideological and political education of students. With the "post-90s" students entering colleges and universities, the ideological and political education work mode will also be innovative, reform and development. The traditional college ideological and political education work more with "classroom", more emphasis on the role of teachers, lack of effectiveness, the way of education can effectively promote the realization of the aim of education, it is difficult to achieve the effect of education. Carry out the "peer support" education in Colleges and universities, make full use of Internet technology, the establishment of a variety of communication education form, breaking the traditional mode of education is an important way of innovation for the development of Ideological and political education. At present, the university students "90" with active thinking, strong self-awareness and many other features, will integrate peer education into the daily ideological and political education work, can fully communicate, play between the students an example of mutual role, improve the ideological and political education work.

It is an effective means of self education for students. Peer education is an important ideological education mode to adapt to the changing times of. Self education is an important means to carry out ideological and political education in Colleges and universities. In the process of education, we should give full play to students' subjective initiative and realize the comprehensive improvement of their own quality. "peer support" education is an important form of self education. Carry out the essence of peer education in Colleges and universities is to let students in academic, psychological and emotional aspects can help each other, through between the students help each 
other to solve their own problems encountered in learning and life. At present, the process of Ideological and political education in Colleges and universities for students to carry out the performance for the education in accordance with the development objectives of education organization plan of moral cultivation and the thoughts on the education of students, colleges and universities in the process of education plays a leading role. Application of "peer aid" mode of education can make similar age, similar background students form a mutual recognition, through peer relations to achieve effective ideological and political education. "peer support" advocate mutual learning, make education both improve learning, under the guidance of both education process are to realize their own value, and the positive role of self education.

It is an innovative way to enhance the appeal of Ideological and Political Education. The work of Ideological and political education stakeholders are mainly embodied in two aspects of students and teachers of Ideological and political theory course instructors, this process is usually the traditional passive mode of education and has explicit education more prominent, is inevitable in the process of education with emotion and psychology. "peer support" education is an important way of Ideological and political education of peer group interaction and the formation of inspiration. Peer group are familiar with, can form a relationship of mutual trust, in the daily life in the process of learning to help each other and interact, promote the formation of identity, and the appeal of Ideological and political education. Compared with the traditional mode of education, "peer support" education is a kind of recessive education, in particular learning environment for students' education can create special effects. The "peer support" into the ideological and political education in Colleges and universities in the process can get the best people to set a good example in a peer group, forming a typical and exemplary role, strengthen ideological and political education inspiration, innovation and development to achieve the ideological and political education work.

\section{The working principle of peer education}

The principle of combining tradition with innovation. With the "90" students into the University, ideological and political education work is facing an important change, to carry out ideological and political education in accordance with the principle of combining tradition and innovation is one of the basic principles of Ideological and political education in Colleges and universities in the new period. In the face of "90" students' active thinking and outstanding personality characteristics, innovation and application of "peer support" education is an effective way to carry out ideological and political education in Colleges and universities. The current rapid development of Internet technology, peer groups of learning communication can improve the effect of peer education through WeChat, micro-blog and QQ communication platform, combining peer education and innovation of the traditional education mode is the basic principle of peer education.

The principle of combining equality with moderation. Equality is an important principle of peer education on the basis of the college. To carry out peer education in Colleges and universities refers to educators and students of mutual learning in the exchange process, the implementation process of the common progress of the function. In this process, educators and educated people should follow the frank and equal way of communication, so that both sides have been promoted to varying degrees, and promote the sound development of Ideological and political education work in Colleges and universities. The principle of moderation is one of the principle of peer education in Colleges and universities. In the process of peer education, based on the concrete analysis to the educated education principle, the rational use of peer education methods, and strictly control the "degree" of thinking, to carry out educational activities in accordance with the education law and the principle of the conditions.

\section{Effective strategies for constructing "peer support" education mode}

To improve the "peer support" education system. "Peer coaching" education system is an important way to promote the ideological and political education of College students. Improve the "peer support" education system is an important guarantee for improving the comprehensive quality 
of College students. Universities can through the selection of student cadres as the ideological and political instructors part-time students, starting from the characteristics and the growth process of the students, the individualized and family education into peer support in the process of training students to establish a correct outlook on life, world outlook and values. At the same time, make clear the assessment methods and standards and reward mechanism to make the management of college students scientific and standardized, and promote the innovation and development of Ideological and political education work.

To strengthen the comprehensive ability of peer educators. The overall level of peer education professional education is an important factor affecting the effectiveness of peer support education. Improve the professional ability of peer educators is an important issue in the ideological and political education work in Colleges and universities are facing. On the one hand, the College Ideological and political education management departments should carry out the education organization through a typical case analysis, lectures and other forms of situational peer educators professional knowledge training, make peer educators can better grasp the methods of work, make effective and smooth. At the same time, in the process of making training plan and program of the corresponding, to plan according to the actual needs of students and their own characteristics, and finally improve strengthen the comprehensive ability of the peer educators.

Build a multi-dimensional education platform. Build a multi-dimensional education platform is the effective strategy of constructing "peer support" education mode. On the one hand, to construct the application through Internet technology to build the network of "peer support" education platform. Peer support group discussion, consultation and other related activities by answering the advantages of the Internet application network, all kinds of problems timely solve team members. On the other side, the construction of class "peer support" education platform, class through theme class meetings and other related activities, the formation of mutual awareness, to create a good environment of peer education. In addition, the construction of campus community peer education platform is an important way of peer mutual education ". Important planners association organization in universities campus cultural activities, have the same hobbies and similar personalities of the students are involved in the same group, the activities of peer education can make the education effect is more obvious.

\section{Acknowledgements}

The Department of education of Jilin province " 13th Five-Year " ordinary program: analysis of College Students' employment psychology and negative peer support "education mode" (GH170074) is one of the results.

\section{References}

[1] Xu justice. Students [D]. of peer education of Liaoning University, 2015.

[2] Jin Yan Yu. Peer education in Ideological and political education in Universities of Jiamusi [J]. Journal of Career Academy, 2014, (09): 107-108..

[3] Huifang. Peer education in the sense of the use of [J]. education in the training of College Students' social responsibility research, 2014, (04): 106-107.

[4] Pan Aihua. Peer education mode in Ideological and political education in the practice of [J]. School of Party construction and ideological education, 2011, (20): 45-46.

[5] left the triumph of single Asia. Moral education in Colleges and universities in student peer education [J]. Journal of Zhejiang University of Media and Communications, 2011,18 (03): 101-105.

[6] Zhu Xiaotong, Chen Xiaomei, Liu Nan. College students' peer education theory and practice of [J]. education in Heilongjiang (higher education research and evaluation), 2010 (08): 6-7. 